\title{
Defamation According to Law Number 19 of 2016 Regarding ITE
}

\author{
Widodo Budidarmo \\ \{wbudidarmo@unis.ac.id\} \\ Universitas Borobudur, Jakarta, Indonesia
}

\begin{abstract}
This paper presents the matter of criticism as per Law Number 19 of 2016 concerning ITE. By utilizing the standardizing juridical exploration strategy reasons that the criminal demonstration of maligning is controlled in Law Number 19 of 2016 in Article 27, 28, and Article 29 which restricts appropriating nor communicating nor making electronic data open, which has an affront nor criticism charge.
\end{abstract}

Keywords: Reputation; ITE; Pollution; Criminal; Law Number 19 of 2016

\section{Introduction}

The advancement of data and innovation in the period of globalization is rapidly growing. Humans are attempting to make various innovations to develop and perfect numerous types of technology as supporting facilities that can help many aspects of everyday human life. Information technology that is rapidly evolving causes changes in the pattern of activities and human life so that it directly affects the emergence of new types of legal acts and events.

Human life is indivisible from technology, thus making a new world for human development and interaction. Technology that has penetrated human life began to take over life in the real world into the virtual world. Devices and equipment are also evolving to make human life effortless. From shopping to health, everything can be taken over by technology. The rapid development and the need for technology create a new world with new habits and procedures.

The new world provided by technology changes the habits and patterns of human life. Interactions that are all limited to the reach of the eye turn into application and quota restrictions. Devices and applications are also evolving to facilitate the needs of human interaction in cyberspace. Devices or tools used in communicating and exchanging information from the rapid development of technology give rise to various applications. Many emerging social media applications are functional in communicating. Social media application content enters all network forms; start from Facebook, Twitter, Line, Instagram, Whats App, and many more. Popularity achievement is one of the competitions through social media is visible in social media Facebook where the number of 'friends' is the size. Therefore, people make friends with anyone who appears on their smartphone screen, whether they have met or not, people from the same city or far abroad.

On the one hand, technology is beneficial for human life but can also have a negative impact. For example, spreading false information or often called hoax news. If it harms 
another person, offends or attacks a person, and ruins their good name, his actions are called a criminal act of defamation. Recently, there have been frequent criminal acts of defamation committed by various parties. The causes are varied, from reporting events in the media, revealing research results, reporting a crime, and other actions that cause the perpetrator to be subject to criminal sanctions, where is a punishment given to a person because he has committed a crime, where the consequences of his actions cause harm to others.

These legal acts and events are using technology to disseminate information. The legal actions are categorized as electronic transactions according to the legitimate definition of the provisions of Article 1(2) of the Law of the Republic of Indonesia Number 11 of 2008 concerning Information and Electronic Transactions (further on this archive curtailed as UU ITE) states that: "Electronic Transactions are legitimate demonstrations done utilizing PCs, networks Computers, or potentially other electronic media". [1] Ease for convenience is obtained by utilizing this limitless technology. But against this convenience, it must be watched out and manipulated so it will not ensnare users. Technology is a perspective and experience that shapes how we act, use tools, and relate to the world of life. As with the above basis, this paper presents the matter of defamation according to Law Number 19 of 2016 concerning ITE.

\section{Method}

This research is normative juridical research, namely legal research on legal studies.[2] The data obtained were analyzed by qualitative descriptive analysis, namely an analysis based on the development of the problem according to the data obtained through the literature. Then, a conclusion was drawn by following the data obtained.[3]

\section{Discussion}

In the laws and guidelines in Indonesia, slander (affront) is controlled and figured in Article 310 of the Criminal Code comprises of 3 (three) sections. Section 1 expressed that whoever purposely assaults somebody's honor or notoriety, by blaming something, with points so it is known to the general population, is undermined with slander, with a greatest detainment of nine months or a most extreme fine of $\mathrm{Rp}$. 300.000, - . Besides, section 2 expresses that if the demonstration is completed recorded as a hard copy or in a picture that is communicated, shown, or posted in broad daylight, then, at that point, the individuals who are blameworthy, due to composed criticism, are compromised with a limit of one year and four months detainment or a most extreme fine of Rp. 300.000, - . Then again, section 3 expresses that if a conspicuous demonstration submitted for the public interest or constrained guarding oneself is avoided as composed criticism or slander.

Therefore, reviewing the provisions of Article 310, it has been formulated that defamation actions can be in the form of:

a. Verbal insulting (smood) - Article 310 paragraph 1 .

b. Written insulting (smoodschrift) - Article 310 paragraph 2.

Meanwhile, prohibited acts are actions that are carried out "deliberately" to violate the honor or assault the honor or great name of others. Along these lines, the components of maligning or affront as indicated by Article 310 of the Criminal Code are:

a. Purposely; 
b. attacking honor or reputation;

c. accusing of committing an act;

d. broadcasting the accusations for the public to know.

If the elements of insult or defamation are only spoken (verbal insulting), then the act is classified in Article 310 Paragraph 1 of the Criminal Code. However, if these elements are carried out through letters or pictures, that are broadcasted, shown, or pasted (written insulting), the perpetrators can be charged with or subject to legal sanctions in Article 310 paragraph 2 of the Criminal Code.

Cyber Crime is a crime in cyberspace. The classification of criminal acts regarding cybercrime is explained in the ITE Law Articles 27 to 37. The construction of these articles in more detail regulates the development of traditional crime modes as stated in the Criminal Code.[4] One example of cybercrime is defamation through electronic social media because it is using electronic media. The lack of public awareness in using the internet wisely causes many problems.

The criminal act of defamation is an act attacking honor or reputation. Assault on reputation is conveying words (words or series of words/sentences) by facilitating certain actions that aim at the reputation and good name of people that can desecrate and humiliate the person's sense of self-esteem or dignity. [5] In particular, defamation is regulated in Article 27 Paragraph 3 of Law Number 19 of 2016 concerning ITE.

By observing the content elements of the Article, each element of a crime does not stand alone, always has a relationship with other elements. Consequently, one can find out the reprehensible reason or why a prohibited act against the law, in this case, is the act of "without rights" distributing, transmitting, or making electronic information accessible.[6] It means that people who have the right to carry out the demonstration of circulating, sending, making available electronic data should not be penalized. However, the distributed information is insulting to others.

Put-downs in the Criminal Code and the ITE Law have a distinction in the Criminal Code that is just a conventional offense, as expressed by Jan Remmelink that, "Formal offense is a criminal demonstration which in the enactment is adequate to allude to explicit demonstrations or omissions.[7] One of the proper offenses is in Article 310 of the Criminal Code. In the mean time, the ITE Law just manages material offenses. The ITE Law just defines the extension of demonstrations of affront and slander through the internet or hardware, while the capability of offenses actually alludes to its family, in particular the detailing of criminal demonstrations contained in the articles in the Criminal Code.

To avoid multiple interpretations of these provisions, the Elucidation of Article 27 section (3) of the most recent ITE Law adds a clarification of the expression "circulating as well as sending or potentially making electronic data and additionally electronic records available. The explanation is described as follows:

a. What is implied by "circulating" is sending as well as scattering electronic data and additionally electronic records to many individuals or different gatherings through electronic frameworks.

b. What is implied by "communicating" is sending electronic data or potentially electronic records addressed to one more party through the electronic framework.

c. What is implied by "make open" are generally activities other than disseminating and communicating through electronic frameworks that cause electronic data as well as electronic reports to be known to different gatherings or general society.

In light of this component, there are two featured articles, in particular electronic data and electronic reports. The arrangements of passage (1) Article 5 of the ITE Law expresses that 
electronic data and electronic archives are legitimate proof. It is reaffirmed in passage (2) that its position is an expansion of substantial bits of proof adhering to the procedural law material in Indonesia. Like the past depiction, this component is arranged by words "and/likewise/or" so the clarification needn't bother with any redundancy. Article 1 number 1 of the ITE Law restricts the legitimate meaning of the significance of electronic data. Electronic data is one or a bunch of electronic information, including however not restricted to composing, sound, pictures, maps, plans, photographs, electronic information trade (EDI), electronic mail (electronic mail), message, wire, telecopy, handled letters, signs, numbers, Access Codes, images, or holes that have meaning or are justifiable by individuals.

As per the Constitutional Court Decision Number 50/PUU-VI/2008, the appreciation of the rules contained in Article 27 fragment 3 of the ITE Law as for affronts or possibly investigation can't be restricted from its sort, unequivocally the criminal law standards contained in Chapter XVI concerning aggravating that contained in Article 310 and Article 311 of the Criminal Code. So that, unavoidably Article 27 section 3 of the ITE Law should be related with Article 310 and Article 311 of the Criminal Code. Thusly, all pieces of the criminal display of investigation in Article 27 section 3 infer the strategy and substance of the maligning in Articles 310 and 311 of the Criminal Code.

The forbiddance of containing affronts as directed in Article 27 and Article 28 of Law Number 19 of 2016 is made to secure the freedoms of people and foundations in light of the fact that the data that we will distribute ought to have gotten authorization from the individual concerned so the individual concerned doesn't feel hurt by the demonstration so it very well may be considered responsible.

The defamation article in the ITE Law does indeed cause controversy. It is considered that this is the emergence of a new style of rubber article or hatzaaiarticleen. This article is also considered crueler than the defamation article in the Criminal Code because there is a wide disparity in terms of punishment. Criminal sanctions regulated by the ITE Law are higher than the articles in the Criminal Code with the maximum number is six years in prison and is one of the conditions for people to be detained first in the investigation process compared to Article 310 of the Criminal Code that just gives a danger of 9 months detainment. In this manner, the substance of the allegation is something very similar, however under the ITE Law, the discipline given is heavier than the Criminal Code. Though in the arrangements of Article 27 passage 3 and Article 45 section 1 of the ITE Law, there is no reasonable meaning of what is implied by affront or slander.

In like way, picking if the part has satisfied stigmatizing, required suggest Article 311 of the Criminal Code. Incredibly, the Constitutional Court has widely likewise declared the presence of the offending article in the ITE Law. In its choice, the Constitutional Court imparted that the state has the situation to limit the dissemination/transmission of such information as a part of protecting inhabitants' advantages from risks of misuses or defamation attacks. Article 27 entry 3 is declared by the Constitutional Court not to conflict with the 1945 Constitution.

\section{Conclusion}

The wrongdoing of criticism is controlled exhaustively and planned in the Criminal Code Articles 310 and 311. The components of criticism or affront as per Article 310 of the Criminal Code are: (1) deliberately; (2) assaulting honor or notoriety; (3) blaming for carrying out a demonstration; (4) telecom the allegations for general society to know. In the event that 
the components of affront or maligning are just spoken (verbal annoying), the demonstration is arranged in Article 310 passage 1 of the Criminal Code. Be that as it may, if these components are completed utilizing letters or pictures communicated, shown, or stuck (composed annoying), the culprits can be accused of or dependent upon legitimate approvals in Article 310 section 2 of the Criminal Code. Be that as it may, not all criminal demonstrations of slander are culpable, if the demonstration is carried out in the public interest or compelled to protect itself (Article 310 passage 3 of the Criminal Code). In submitting analysis or sentiments, it is ensured by Human Rights and material laws and guidelines.

\section{References}

[1] "UU no. 11 of 2008 Regarding Information and Electronic Transactions." .

[2] M. H. Dr. johnny ibrahim,SH., Normative Legal Research Theory \& Methodology. 2006.

[3] J. Ibrahim, "Normative Legal Research Theories and Methods," Bayu Media, Malang, 2006.

[4] Maskun, Cyber Crime. Jakarta: Kencana Prenadamedia Group, 2013.

[5] A. Chazawi, Criminal Law Positive Insult. Surabaya: ITS Press, 2009.

[6] S. Sunarso, Information and Electronic Transaction Law. Jakarta: Rineka Cipta, 2017.

[7] J. Remmelink, Introduction to Criminal Law Material 1 (Inleiding Tot De Studie Van Het Nederlandse Strafrecht). Yogyakarta: Maharsa, 2014. 